\title{
Guided sputum sample collection and culture contamination rates in the diagnosis of pulmonary $\mathrm{TB}^{* * * *}$
}

\author{
Associação entre coleta de escarro guiada e taxas de \\ contaminação de culturas para o diagnóstico de TB pulmonar \\ Ethel Leonor Noia Maciel, Thiago Nascimento do Prado, \\ Renata Lyrio Peres, Moises Palaci, John L. Johnson, Reynaldo Dietze
}

\begin{abstract}
A comparative study to evaluate contamination in cultures of morning sputum samples, comparing those collected at home under currently recommended conditions and those collected under supervision after patient orientation and education. The home and supervised collection groups produced 43 and 76 sputum samples, respectively. The contamination rate was nearly 3-times higher among samples collected at home than among those collected under supervision (37\% vs. 13\%, $\mathrm{p}<0.05 ; \mathrm{OR}=0.25$ ). The simple educational and hygiene measures described can decrease the contamination rate among sputum samples collected for diagnostic culture.
\end{abstract}

Keywords: Tuberculosis/diagnosis; Sputum/microbiology; Culture techniques.

\section{Resumo}

Realizou-se um estudo comparativo para avaliar a contaminação em culturas de amostras matinais de escarro coletadas em domicílio sob condições recomendadas atualmente e amostras coletadas sob supervisão após orientação e educação dos pacientes. Os grupos de coleta domiciliar e supervisionada produziram 43 e 76 amostras, respectivamente. A taxa de contaminação foi aproximadamente 3 vezes maior nas amostras coletadas em domicílio do que naquelas coletadas sob supervisão (37\% vs.13\%; $p<0,05 ; 0 R=0,25)$. As simples medidas educacionais e de higiene descritas podem reduzir a taxa de contaminação de amostras de escarro coletadas para culturas diagnósticas.

Descritores: Tuberculose/diagnóstico, Escarro/microbiologia; Técnicas de cultura.

Sputum culture is more sensitive than is sputum smear microscopy for the diagnosis of TB. Sputum culture also has the advantage of allowing recovery of the mycobacteria for identification and drug susceptibility testing. Although technically simple, the collection, storage and transportation of sputum samples must be performed in an appropriate manner, since failure to do so can increase culture contamination rates and decrease culture sensitivity. ${ }^{(1,2)}$ Few studies have attempted to identify the best method for collecting sputum samples for TB diagnosis. ${ }^{(3,4)}$ The present study was designed to evaluate the culture contamination rate in morning sputum samples, comparing those collected using the routine procedures established by the Brazilian Programa Nacional de Controle da Tuberculose (PNCT, National Tuberculosis Control Program) with those collected after toothbrushing and detailed patient education.

Between 2003 and 2006, a total of 367 patients with TB were treated at the Universidade Federal do Espírito Santo (UFES, Federal University of Espírito Santo) Cassiano Antonio Moraes University Hospital, located in the city of Vitória, Brazil. All patients receiving TB treatment between June and December of 2006 ( $n=119)$ were invited and agreed to

\footnotetext{
* Study carried out at the Clinical Research Center of the Universidade Federal do Espirito Santo - UFES, Federal University of Espírito Santo - Vitória, Brazil.

Correspondence to: Ethel Leonor Noia Maciel. Av. Marechal Campos, 1468, Maruipe, CEP 29040-091, Vitória, ES, Brasil.

Tel 5527 3335-7210. E-mail: emaciel@ndi.ufes.br

Financial support: The laboratory work for this study has been funded in part by contract no. N01-A195383 and N01-Al-70022 (Tuberculosis Prevention and Control Research Unit) of the National Institute of Allergy and Infectious Diseases, National Institutes of Health, U.S.A. and funding from Edital MCT/CNPq/MS-SCTIE-DECIT 25/2006 - Estudo de Doenças Negligenciadas.

Submitted: 1 August 2008. Accepted, after review: 7 November 2008.

**A versão completa em português deste artigo está disponível em www.jornaldepneumologia.com.br
} 
Table 1 - Study population profile.

\begin{tabular}{lccc}
\hline \multicolumn{1}{c}{ Characteristic } & Intervention group & Control group & $\mathrm{p}$ \\
\cline { 2 - 3 } & $(\mathrm{n}=76)$ & $(\mathrm{n}=43)$ & \\
\hline Male gender, $\mathrm{n}(\%)$ & $42(55.3)$ & $23(53.4)$ & 0.856 \\
Age, mean \pm SD & $36.0 \pm 10.5$ & $36.9 \pm 13.0$ & 0.254 \\
$\geq 2$ months of TB treatment, $\mathrm{n}(\%)$ & $36(47)$ & $18(42)$ & 0.532 \\
\hline
\end{tabular}

participate in the study. The UFES Institutional Review Board approved the study design, and all participating patients gave written informed consent.

The 119 patients were divided into two groups: control $(\mathrm{n}=43)$ and intervention $(\mathrm{n}=76)$.

In the control group, sputum samples were collected at home using routine PNCT procedures. Subjects were instructed to collect the first morning sample after fasting the previous night and to collect two samples on consecutive days. The first sample was stored in the refrigerator from collection until the next day, when the second sample was collected and both samples were delivered to the TB clinic. Only the second-day sample was used in this study.

In the intervention group, the sputum samples were collected under direct supervision and using standardized guidance. Each intervention group patient received the following instructions:
- Come to the clinic for collection of the first morning sample after fasting the previous night.

- Use a toothbrush (provided by the study), without toothpaste, to gently remove any food residue from your teeth and gums.

- Wash your hands with soap and water, drying them with paper towels.

- Do not touch the inside of the container with your hands or mouth.

- Keep the container capped during sputum collection (between each addition).

- Collect at least $10 \mathrm{~mL}$ of sputum if possible.

Sputum samples were processed in the Mycobacteriology Laboratory of the UFES Center for Infectious Diseases. Samples were reduced for 5 min with dithiothreitol (final concentration, $0.1 \%$ ), after which they were decontaminated at room temperature for 15 min with $\mathrm{NaOH}$ and $\mathrm{NaCl}$ (final concentrations, 1.25\% and 0.72\%, respectively). Samples were then neutralized

Table 2 - Quality of sputum samples (volume and aspect), culture results and contamination rates.

\begin{tabular}{|c|c|c|c|}
\hline Variable & $\begin{array}{c}\text { Intervention group } \\
(\mathrm{n}=76) \\
\mathrm{n}(\%)\end{array}$ & $\begin{array}{c}\text { Control group } \\
(n=43) \\
n(\%)\end{array}$ & $\mathrm{p}$ \\
\hline \multicolumn{4}{|l|}{ Volume } \\
\hline$\geq 5$ mL (adequate), $\mathrm{n}(\%)$ & $76(100)$ & $10(23)$ & $<0.001^{*}$ \\
\hline$<5 \mathrm{~mL}$ (inadequate), $\mathrm{n}(\%)$ & $0(0)$ & $33(77)$ & \\
\hline \multicolumn{4}{|l|}{ Aspect } \\
\hline Mucopurulent (appropriate), n (\%) & $76(100)$ & $36(84)$ & $<0.001^{*}$ \\
\hline Saliva (inappropriate), n (\%) & $0(0)$ & $7(16)$ & \\
\hline \multicolumn{4}{|l|}{ Volume and aspect } \\
\hline Appropriate, n (\%) & $76(100)$ & $9(21)$ & $<0.001^{*}$ \\
\hline Inappropriate, n (\%) & $0(0)$ & $34(79)$ & \\
\hline \multicolumn{4}{|l|}{ Culture results } \\
\hline Positive, $\mathrm{n}(\%)$ & $32(42)$ & $14(33)$ & 0.305 \\
\hline Negative, n (\%) & $34(45)$ & $13(30)$ & 0.121 \\
\hline \multicolumn{4}{|l|}{ Culture contamination } \\
\hline Contaminated, n (\%) & $10(13)$ & $16(37)$ & \\
\hline Uncontaminated, n (\%) & $66(87)$ & $27(62)$ & $0.002^{* *}$ \\
\hline
\end{tabular}


with phosphate-buffered saline and centrifuged at $4000 \mathrm{~g}$ for $15 \mathrm{~min}$. The pellet was cultured on solid Ogawa medium and in enriched BACTEC 12B liquid medium. ${ }^{(5)}$ Cultures were defined as contaminated if either culture medium was contaminated. We used t-tests to analyze difference between means. Fisher's exact test was used to compare proportions, with ORs and the corresponding 95\% Cls. Data were analyzed using the Stata program, version 9.0 (Stata Corp., College Station, TX, USA). Values of $p<0.05$ were considered statistically significant.

Patients in the intervention and control groups were similar in terms of gender, age and the duration of TB treatment prior to sputum sample collection (Table 1). In the intervention group, $100 \%$ of the sputum samples were classified as adequate in volume ( $\geq 5 \mathrm{~mL}$ ), compared with only $23 \%$ of the control group samples (Table 2). In terms of the aspect of the sputum samples, $100 \%$ and $83 \%$ of the intervention and control group samples, respectively, were classified as mucopurulent $(p<0.05)$. The TB positivity rate, as determined by direct sputum smear microscopy to detect acid-fast bacilli, was similar in the intervention and control groups: $4 \%$ and $7 \%$, respectively $(p=0.47)$. Culture contamination was identified in $10(13 \%)$ of the 76 intervention group samples, compared with $16(37 \%)$ of the 43 control group samples ( $p=0.002 ;$ OR $=0.25 ; 95 \% \mathrm{Cl}: 0.09-0.69)$.

Sputum culture is an important diagnostic tool for TB. However, operational aspects of sputum culture, such as the cost of implementation, the time required to obtain the result and culture contamination, have limited its use by laboratories in developing countries. ${ }^{(6)}$ Two recent studies examined the contribution of patient education to the diagnostic yield of sputum microscopy. ${ }^{(3,4)}$ In one of those studies, the rate at which TB was diagnosed was $15.1 \%$ higher among patients receiving orientation on how to collect sputum samples than among those who did not. In the other study, a similar, albeit smaller, increase was observed: 5\% among women and 3\% among men. The smear positivity rates reported in those studies were lower than those observed in our study, which focused on the effect of sputum collection guidance and simple hygiene measures (hand washing, toothbrushing and handling the specimen container correctly) to decrease culture contamination rates.

We found that these simple measures resulted in a nearly 3-fold decrease in the culture contamination rate. Our intervention involved several measures, and we cannot, based on our data, single out any one of those measures as having played a greater role in that decrease. In this era of multidrug-resistant and extensively drugresistant $\mathrm{TB}$, many entities, including the World Health Organization, have placed more emphasis on expanding capacity for sputum culture and drug susceptibility testing. ${ }^{(7,8)}$ To that end, simple educational measures might help decrease the number of contaminated cultures and optimize the use of limited laboratory resources.

\section{References}

1. Brodie D, Schluger NW. The diagnosis of tuberculosis. Clin Chest Med. 2005;26(2):247-71, vi.

2. Steingart KR, Ng V, Henry M, Hopewell PC, Ramsay A, Cunningham J, et al. Sputum processing methods to improve the sensitivity of smear microscopy for tuberculosis: a systematic review. Lancet Infect Dis. 2006;6(10):664-74.

3. Alisjahbana B, van Crevel R, Danusantoso H, Gartinah T, Soemantri ES, Nelwan RH, et al. Better patient instruction for sputum sampling can improve microscopic tuberculosis diagnosis. Int $\mathrm{J}$ Tuberc lung Dis. 2005;9(7):814-7.

4. Khan MS, Dar 0, Sismanidis C, Shah K, GodfreyFaussett P. Improvement of tuberculosis case detection and reduction of discrepancies between men and women by simple sputum-submission instructions: a pragmatic randomised controlled trial. Lancet. 2007;369(9577):1955-60.

5. Susemihl AA, Ferrazolli L, Ueki SY, Gimenez RD, Palaci M. Avaliação do método de Ogawa- Kudoh para o cultivo de micobactérias. Rev Bras Pat Clin. 1993;29(2):51-4.

6. Macq J, Solis A, Velázquez H, Dujardin B. Informing the TB suspect for sputum sample collection and communicating laboratory results in Nicaragua: a neglected process in tuberculosis case finding. Salud Publica Mex. 2005;47(4):303-7.

7. World Health Organization. Global Tuberculosis Control: Surveillance, Planning, Financing. WHO Report 2006. Geneva: World Health Organization; 2006.

8. World Health Organization. Strategic Approach for the Strengthening of Laboratory Services for Tuberculosis Control, 2006-2009. World Health Organization: WHO/ $\mathrm{HTM} / \mathrm{TB} / 2006.364 ; 2006$. 


\section{About the authors}

\section{Ethel Leonor Noia Maciel}

Adjunct Professor of Epidemiology. Universidade Federal do Espirito Santo - UFES, Federal University of Espírito Santo - Vitória, Brazil.

\section{Thiago Nascimento do Prado}

Masters Student in the Postgraduate Program in Infectious Diseases. Universidade Federal do Espirito Santo - UFES, Federal University of Espírito Santo - Vitória, Brazil.

\section{Renata Lyrio Peres}

Masters Student in the Postgraduate Program in Infectious Diseases. Universidade Federal do Espirito Santo - UFES, Federal University of Espírito Santo - Vitória, Brazil.

\section{Moises Palaci}

Coordinator of the Laboratory of Microbiology. Infectious Disease Center, Universidade Federal do Espirito Santo - UFES, Federal University of Espírito Santo - Vitória, Brazil.

John L. Johnson

Coordinator of the Clinical Trial Center. Tuberculosis Research Unit, Case Western Reserve University, Cleveland, OH, USA.

\section{Reynaldo Dietze}

Coordinator of the Infectious Disease Center. Universidade Federal do Espirito Santo - UFES, Federal University of Espírito Santo Vitória, Brazil. 